Oryx, February 1974, in the course of which he characteristically pointed out that western scientists often claim to have 'discovered' information well known to the local inhabitants whom nobody had asked.

There was nobody like Tom Harrisson for blowing away cobwebs, sweeping away outworn rules, and penetrating behind bureaucratic verbiage and obstructions - he had after all been a (most unorthodox) Government servant himself. Indeed perhaps his greatest value to the conservation movement was his readiness to speak his mind, however unpalatable his views might be.

R.F.

\title{
Erica Critchley
}

When Erica Critchley died last September President Kaunda wrote in her book of memory: 'To the memory of one who loved Zambia so much; she cared for human and natural resources. Let what she stood for not be forgotten by Zambia - especially its youth'. Her ashes were scattered from a Zambian Air Force helicopter over her old farm and the Blue Lagoon National Park which was her home and which owes its existence as a park to her and her husband Ronnie. Together in 1952 they founded what is now the Wildlife Conservation Society of Zambia, she serving as Secretary for 20 years while Ronnie was President, both retiring in 1972 to become Honorary Life Presidents. The Society's achievements - Operation Noah, school camps and Chongolo Clubs, Black Lechwe magazine and not least the profound influence on government thinking and attitudes to wildlife, owed much to their immense drive and initiative. Erica was a forthright and fearless champion. Ian Grimwood, who was in the Game and Tsetse Control Department, writes that, in the days before Northern Rhodesia became independent as Zambia, 'her outspoken criticism of government apathy towards wildlife acted as a magnificent goad and greatly helped the Department to introduce several very necessary reforms. On the constructive side it was she who appreciated the need for vocal and well informed public opinion'.

David Shepherd, the wildlife artist who has done some of his best work in (and in aid of) Zambia, writes:

'The loss to Africa's wildlife is beyond measure. She was one of those rare people to whom one could really apply the overused word "dedicated" - indeed she was fanatical - but above all Erica was a very real and colourful character, and the hospitality with which she and Ronnie rewarded those who made the long and dusty journey to Blue Lagoon is something their legion of friends will never forget - in that cool haven, surrounded on all sides by the vast wilderness of the Kafue Flats, where the great herds of lechwe come right up to the house in times of flood, and there was the strong possibility of a tame baby hippo in the bathroom, or a leopard cub sharing the rug with their great Dane. She and Ronnie fought an almost single-handed crusade against the poachers who threatened their wild animals - woe betide any poacher who fell into Erica's hands! She would write explosive letters, rousing the all too apathetic or uninterested officials into action making enemies perhaps, but also friends. Most important of all, however, is the work done by Erica and Ronnie for the Chongolo Clubs - preaching conservation of wildlife and the environment to the children. This really matters.

'Animals came first to Erica and she undoubtedly did great work in establishing the great conservation awareness which now manifests itself in Zambia - inspired by President Kaunda himself.' 